\title{
Stress Corrosion cracking Testing in Supercritical Carbon Dioxide
}

\author{
Sebastien Teysseyre
}

September 2016

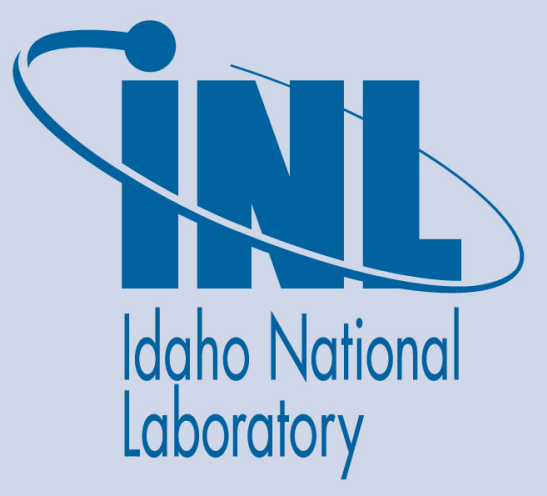

The INL is a U.S. Department of Energy National Laboratory operated by Battelle Energy Alliance 


\title{
Stress Corrosion cracking Testing in Supercritical Carbon Dioxide
}

\author{
Sebastien Teysseyre
}

September 2016

Idaho National Laboratory Idaho Falls, Idaho 83415

http://www.inl.gov

Prepared for the U.S. Department of Energy Office of Nuclear Energy Under DOE Idaho Operations Office

Contract DE-AC07-05ID14517 
Project Number: $16-050$

Title: 16-050 - Stress Corrosion cracking Testing in Supercritical Carbon Dioxide

Principal Investigator: Sebastien Teysseyre ${ }^{1}$

Co-Investigators:, Julie Tucker ${ }^{2}$, Piyush Sabharwall ${ }^{1}$, Joe Palmer ${ }^{1}$, Robert Fox ${ }^{1}$

${ }^{1} \mathrm{INL}^{2}$ Oregon State University

\section{General Project Description:}

This project is developing testing capability to address stress corrosion cracking issues in supercritical carbon dioxide. In addition, this project is generating corrosion data. This work aims to help select structural materials for supercritical carbon dioxide energy systems.

\section{Summary:}

In fiscal year 2015, a corrosion loop was built at Oregon State University. This loop is used to generate corrosion data on Ni-based alloys (e.g., Inconel 625, Haynes 282) and their joints (diffusion bonding, laser welding, brazes) at temperatures ranging from $300^{\circ} \mathrm{C}$ to $750^{\circ} \mathrm{C}$. This fiscal year, in addition to analyzing the corrosion data (nature of the oxide, degradation of the underlying material...), we are working on adapting a technology that was developed at INL for stress corrosion cracking testing in nuclear reactor to the corrosion loop. This work will allow us to perform the first in line measurement of stress corrosion cracking crack growth in supercritical carbon dioxide.

The characterization of corrosion in supercritical $\mathrm{CO}_{2}$ led to the following information:

- At $750^{\circ} \mathrm{C}$ for $600 \mathrm{~h}$ lead to significant void density underneath the oxide layer and internal oxidation. High concentration of aluminum along the oxidized grain boundary has been observed. The primary surface oxide was identified as $\mathrm{Cr}$.

- At $650^{\circ} \mathrm{C}$ oxide pegs or protrusions growing into the matrix were shown have a greater depth and density with longer exposure times

- At $650^{\circ} \mathrm{C}$ there was noticeable evidence of precipitation at grain boundaries and intragranularly; however, underneath the scale, there was a precipitate-free zone (PFZ) that is also associated with a $\mathrm{Cr}$ depletion area and a layer of newly formed, possibly recrystallized grains. The as received sample has no recrystallized zone compared to the cross-sectional results seen after 200 and 600 hours.

- At $650^{\circ} \mathrm{C}$ at various time intervals, recrystallization zone underneath the oxide was observed.

- Mean thickness of scale increased with a function of temperature but stayed relatively similar as a function of time at $650^{\circ} \mathrm{C}$. The PFZ grew slightly as a function of time.

With regard with the implementation of stress corrosion cracking testing capability, the implementation of the stress corrosion cracking monitoring and control in existing corrosion sets-up has been performed. The requirements to perform stress corrosion cracking in this environment (high temperature and pressure) were investigated and it was confirmed that the bellow system we are 
considering will be appropriate. The experiment control system was designed and the componens were purchased.

\section{Benefits to DOE:}

S-CO2 Brayton conversion will benefit efforts in the offices of Nuclear Energy, Fossil Energy, Energy Efficiency and Renewable Energy. To be able to deploy such technology, it is necessary to select suitable materials to be used for the components working in this environment. This work develops stress corrosion cracking testing capability to generate the first stress corrosion cracking data in supercritical $\mathrm{CO}_{2}$ and support corrosion experiments.

This work equips INL and its partner with the equipment and knowledge to address stress corrosion cracking and its mitigation for supercritical $\mathrm{CO}_{2}$ systems. Vito Cedro (NETL project manager) already expressed interest in this work and its future development.

\section{Presentations:}

\section{Presentations with proceedings:}

1. L. Teeter, N. Huerta, O. Dogan, M. Ziomek-Moroz, R. Oleksak, D. Oryshchyn, C. Disenhof, J. Baltrus, and J. Tucker, "Corrosion Behavior of Austenitic Stainless Steel in Supercritical CO2 containing O2 and H2O",.229 ${ }^{\text {th }}$ Electrochemical Society Meeting, San Diego, CA,May 29-June2 2016

2. L. Teeter, F. Teng, W. Marcum, J. Kruzic, M. Anderson and J.D. Tucker, "Supercritical Carbon-Dioxide System for Materials Corrosion Testing", Oregon State University Engineering Research Expo, March 4 (2015)

3. L. Teeter, F. Teng, W. Marcum, J. Kruzic, M. Anderson and J.D. Tucker, "Supercritical Carbon-Dioxide System for Materials Corrosion Testing", TMS Annual Meeting and Exhibition, Orlando, Fl, March 15-19 (2015).

4. L. Teeter, B. Adam, W. Marcum, J. Kruzic, M. Anderson and J.D. Tucker, "OSU Supercritical Carbon-Dioxide System for Materials Corrosion Testing”, Idaho National Laboratory, April 20 (2015). [Invited]

5. L. Teeter, B. Adam, W. Marcum, J. Kruzic, M. Anderson and J.D. Tucker, "Corrosion of Energy System Materials in Supercritical Carbon Dioxide (SC-CO2)", EPRI International Conference on Corrosion in Power Plants, San Diego, Ca,October 13 (2015).

\section{Interns, Postdocs, Staff:}

This project is mainly funding one grad student and one undergrad but is also involving other students.

- Lucas Teeters, working on MS in Materials Science, will stay for PhD/ INL LDRD funded and NETL fellowship funded.

- Allison Burns, pre-engineering undergrad, hourly employee/ INL LDRD funded

- Patrick Jarrold, working on BS in Computer Science, support data acquisition, LabVIEW programming/hourly employee, funded by another source

- Ben Adams, working on his PhD in Materials science, funded by another source

- Reyixiati Repukaiti, working on MS in Materials Science, will be funded by NETL fellowship staring in the fall 